\title{
Pollen Quality and Performance in Strawberry Plants Exposed to High-temperature Stress
}

\author{
Nadine Ledesma ${ }^{1}$ and Nobuo Sugiyama \\ Graduate School of Agricultural and Life Sciences, University of Tokyo, Yayoi 1-1-1, Bunkyo-ku, Tokyo \\ 113-8657, Japan
}

\begin{abstract}
ADDITIONAL INDEX WORDS. acetocarmine staining, aniline-blue staining, fluorescence microscopy, Fragaria $\times$ ananassa, in vitro germination, pollen viability

ABstract. The effects of high-temperature stress on pollen viability and in vitro and in vivo germinability were studied in two facultative, short-day strawberries (Fragaria xananassa Duch.), 'Nyoho' and 'Toyonoka.' Plants were exposed to two day/night temperature regimes of either $23^{\circ} \mathrm{C} / 18^{\circ} \mathrm{C}$ (control) or $30{ }^{\circ} \mathrm{C} / 25^{\circ} \mathrm{C}$ (high temperature) from when the first inflorescence became visible until anthesis. Pollen viability in ' $N y o h o$ ' was only slightly affected at $30^{\circ} \mathrm{C} / 25^{\circ} \mathrm{C}$ when compared with pollen from plants grown at $23^{\circ} \mathrm{C} / 18^{\circ} \mathrm{C}$. In 'Toyonoka', however, pollen viability was significantly lower at $30^{\circ} \mathrm{C} / 25^{\circ} \mathrm{C}$ than at $23^{\circ} \mathrm{C} / 18^{\circ} \mathrm{C}$. The in vitro germination percentages were significantly lower in pollen from plants grown at $30{ }^{\circ} \mathrm{C} / 25^{\circ} \mathrm{C}$ and germinated at $30{ }^{\circ} \mathrm{C}$ than from plants grown at $23^{\circ} \mathrm{C} / 18{ }^{\circ} \mathrm{C}$ and germinated at $23{ }^{\circ} \mathrm{C}$ in both cultivars. But the percentages were much lower in 'Toyonoka' than in 'Nyoho', particularly at the $30{ }^{\circ} \mathrm{C}$ germination temperature. Pollen from plants grown at $23^{\circ} \mathrm{C} / 18^{\circ} \mathrm{C}$ also extended longer pollen tubes than pollen grown at $30{ }^{\circ} \mathrm{C} / 25$ ${ }^{\circ} \mathrm{C}$ in both cultivars, but 'Nyoho' had longer pollen tubes than 'Toyonoka' at $30^{\circ} \mathrm{C} / 25^{\circ} \mathrm{C}$. Fluorescence microscopy revealed that most of the 'Nyoho' pollen germinated on the stamen, elongated through the style and reached the ovule regardless of temperature treatment. In 'Toyonoka', pollen germination and elongation were greatly inhibited at 30 ${ }^{\circ} \mathrm{C} / 25^{\circ} \mathrm{C}$, resulting in unfertilized ovules. These results suggest that certain strawberry cultivars produce heat-tolerant pollen, which in turn could result in higher fruit set.
\end{abstract}

High-temperature stress can affect the growth and development of pollen, which in turn can impinge on fruit set and seed development. Specific processes involving pollen that greatly influence fruit set and that have been found to be very sensitive to high temperatures include: 1) viable pollen production; 2) pollen germination in situ; and 3) pollen tube extension down the style and into the ovule (cited in Song et al., 1999).

Poor pollen performance at high temperatures has been shown to directly affect fruit set (Abdul-baki and Stommel, 1995; Cross et al., 2003; Dane et al., 1991; Vara Prasad et al., 2001).In tomato (Lycopersicon esculentum Mill.) plants, in vitro pollen germination and tube growth are significantly inhibited at $33^{\circ} \mathrm{C}$ and 35 ${ }^{\circ} \mathrm{C}$ but not at $25^{\circ} \mathrm{C}$ (Song et al., 1999). Measurements of pollen tube growth in apricot (Prunus armeniaca $\mathrm{L}$.) styles have shown that temperature affects their growth rate: pollen tubes penetrated deeper into the style at 10 and $15^{\circ} \mathrm{C}$ than at higher temperatures (Austin et al., 1998). In Cucurbita pepo L., it has been reported that pollen developed at $20^{\circ} \mathrm{C}$ extends significantly longer pollen tubes in vitro than pollen developed at $30^{\circ} \mathrm{C}$ (Johansson and Stephenson, 1998). Morphological evidence for the negative effects of heat stress on pollen has been documented in bell pepper, (Capsicum annuum L.) (Aloni et al., 2001), pecan [Carya illinoinensis (Wangenh.) K. Koch] (Yates and Sparks, 1993), tobacco (Nicotiana tabacum L.) (Kandasamy and Kristen, 1989), and Arabidopsis thaliana (L.) Heynh. (Kim et al., 2001).

Differences in both fruit and seed set among cultivars of several crop species have been attributed to the different sensitivities of pollen to heat. In bean (Phaseolus vulgaris L.), the heat-sensitive cultivar was found to have indehiscent anthers with abnormal

Received for publication 13 Sept. 2004. Accepted for publication 29 Nov. 2004.

1To whom reprint requests should be addressed.E-mail address: aledesma@mail. ecc.u-tokyo.ac.jp

${ }^{2}$ This paper is a portion of a dissertation submitted as a requirement for the degree of Doctor of Philosophy. pollen when both heat-tolerant and heat-sensitive cultivars were subjected to heat stress 1 to $13 \mathrm{~d}$ before anthesis (Porch and Jahn, 2001). Tomatoes are generally sensitive to heat stress, and according to Sato et al. (2000), only heat-tolerant cultivars can set fruits at $32{ }^{\circ} \mathrm{C}$ day $/ 26^{\circ} \mathrm{C}$ night temperatures. The different responses to heat stress among the tomato cultivars were attributed to differences in the release of pollen grains and their subsequent germination. Lyakh et al. (1991) found that there are genotypic differences in maize (Zea mays L.) pollen germination at high temperatures and that pollen grains resistant to high temperatures $\left(35\right.$ or $26^{\circ} \mathrm{C}$ ) are characterized by a higher germination capacity and better ability to develop normal pollen tubes.

Poor pollen quality in strawberry plants results in low fertilization rates, which in turn lead to a reduction in fruit set (Gilbert and Breen, 1986) and an increase in the formation of malformed fruits called "nubbins" (Kronenberg, 1959). Anther and pollen degeneration are caused by several factors, including inadequate chilling of plants (Risser, 1997), low temperatures $\left(<17^{\circ} \mathrm{C}\right)$ (Braak, 1968), and low light intensity shortly before and during flowering (Smeets, 1976, 1980). Voyiatzis and Paraskevopoulou-Paroussi (2002) compared the germinability of pollen at 20 and $25^{\circ} \mathrm{C}$ in seven strawberry cultivars. They found that some cultivars favored $20{ }^{\circ} \mathrm{C}$ for pollen germination, while others favored the higher temperature. However, there are very few studies on the effect of higher temperatures $\left(>25^{\circ} \mathrm{C}\right)$ on overall pollen performance in strawberry. Such a study would be vital since the optimal temperature for strawberry growth and fruit production is between 10 to $26^{\circ} \mathrm{C}$ (Strick, 1985).

The number of flowers and eventual fruit set directly determine the yield in any crop, and flowering and fruit set are processes highly sensitive to environmental stresses. Both the male and female gametophytes are adversely affected by high temperatures, but it has been shown that the pollen is usually more sensitive than the female part of the flower. Therefore, it is important to study how high-temperature stress can affect pollen performance and quality in strawberry plants. 
The objectives of this study were 1) to determine how high temperatures affect pollen performance in vitro and in vivo;2) to determine if different temperatures during pollen development in the flower and during the germination period affect germination percentage and pollen tube growth; and 3) to compare pollen performance in two leading Japanese strawberries, 'Nyoho' and 'Toyonoka'.

\section{Materials and Methods}

Plant material. Runners from two strawberry cultivars, 'Nyoho' and 'Toyonoka', were rooted in 7-cm polyvinyl pots containing a medium of soil compost (Soil Mix; Sakata Seeds Corp., Yokohama, Japan), granulated soil-derived potting material (Engei-baido, Kureha; Iwaki City, Japan), and vermiculite (4:1:1) in Aug. 2003. After 4 weeks, the rooted plants were moved to a growth chamber with a 10-h daylength under artificial lighting (fluorescent tubes, $80-90 \mu \mathrm{mol} \cdot \mathrm{m}^{-2} \cdot \mathrm{s}^{-1}$ ) and a temperature of 10 ${ }^{\circ} \mathrm{C}$ for flower induction for 3 weeks. Plants were then transplanted into $15-\mathrm{cm}$ plastic pots containing the same growing medium and maintained in a plastic house where the average day/night temperature was $26^{\circ} \mathrm{C} / 15^{\circ} \mathrm{C}$ under natural light conditions.

Heat Stress treatments. When flower buds became visible in early October, five plants of each cultivar were transferred to two growth rooms kept at either $23{ }^{\circ} \mathrm{C}$ day $/ 18{ }^{\circ} \mathrm{C}$ night temperatures (control) or $30{ }^{\circ} \mathrm{C}$ day $/ 25^{\circ} \mathrm{C}$ night temperature (high temperature). A slow-release fertilizer $(6 \mathrm{~N}-4.4 \mathrm{P}-3.7 \mathrm{~K}$; Lilly Miller Brands, Clackamas, Ore.) was applied at $10 \mathrm{~g} /$ pot. Five flowers from each position in the inflorescence were used in each experiment to determine pollen viability and pollen germination in vitro and in vivo.

Pollen viability. Pollen viability was examined by acetocarmine staining. For pollen collection, five fully-opened flowers with dehiscent anthers were sampled from the primary, secondary, and tertiary inflorescences of plants grown at $23{ }^{\circ} \mathrm{C} / 18{ }^{\circ} \mathrm{C}$ and $30^{\circ} \mathrm{C} / 25^{\circ} \mathrm{C}$. The flowers were gently tapped with a pen to collect pollen into a petri dish. The pollen was then mixed and spread with a paintbrush on drops of acetocarmine solution on microslides. After $15 \mathrm{~min}$, viability was examined under a light microscope. Pollen that stained red was considered viable and the percentage of viable pollen among 100 pollen grains was determined for each of the five flowers at each flower position (a total of 500 pollen grains each for primary, secondary, and tertiary flowers).

Pollen germination-IN Vitro and in vivo. For the determination of in vitro pollen germination and pollen tube length, five fully-opened flowers with dehiscent anthers were obtained from each flower position of plants grown at $23{ }^{\circ} \mathrm{C} / 18^{\circ} \mathrm{C}$ and $30{ }^{\circ} \mathrm{C} / 25{ }^{\circ} \mathrm{C}$, and taken to the laboratory. The flowers were gently tapped with a pen to collect pollen into a petri dish. The pollen was then mixed and spread with a paintbrush on drops of germinating medium, which were placed on several microscope slides. The germination medium consisted of $8 \%$ sucrose, $0.6 \%$ agar, and $50 \mathrm{mg} \cdot \mathrm{L}^{-1}$ boric acid. The slides were put in separate petri dishes, where the relative humidity was kept high by lining the petri dish cover with moist filter paper, and then sealed with adhesive tape. Pollen that developed at both temperature treatments $\left(23^{\circ} \mathrm{C} / 18^{\circ} \mathrm{C}\right.$ and $\left.30^{\circ} \mathrm{C} / 25^{\circ} \mathrm{C}\right)$ were germinated under two temperatures, 23 and $30^{\circ} \mathrm{C}$, for $4 \mathrm{~h}$ in the dark. This created four temperature treatment combinations: control temperature (CT) treatment $\left(23^{\circ} \mathrm{C} / 18^{\circ} \mathrm{C}\right.$ at $\left.23^{\circ} \mathrm{C}\right)$; high germination temperature (HGT) treatment $\left(23^{\circ} \mathrm{C} / 18{ }^{\circ} \mathrm{C}\right.$ at $\left.30^{\circ} \mathrm{C}\right)$; relieving temperature
(RT) treatment $\left(30^{\circ} \mathrm{C} / 25^{\circ} \mathrm{C}\right.$ at $\left.23{ }^{\circ} \mathrm{C}\right)$; and high-temperature (HT) treatment $\left(30^{\circ} \mathrm{C} / 25^{\circ} \mathrm{C}\right.$ at $\left.30^{\circ} \mathrm{C}\right)$. Pollen germination was examined under a light microscope. The germination percentage for 100 pollen grains from each flower (a total of 500 pollen grains from each flower position) was calculated. The pollen tube lengths of 10 grains from each flower (a total of 50 pollen grains for each flower position) were also measured on photographs taken with a camera mounted on the microscope. Pollen was considered to have germinated when the length of the pollen tube was equal to or longer than the diameter of the pollen.

For in vivo pollen germination, five fully-opened flowers with dehiscent anthers from each flower position of plants grown at $23^{\circ} \mathrm{C} / 18^{\circ} \mathrm{C}$ and $30^{\circ} \mathrm{C} / 25^{\circ} \mathrm{C}$ were pollinated with a paintbrush. After $24 \mathrm{~h}$, the flowers were collected and the receptacle with the pistils and ovaries was separated and fixed in FAA solution (5:5:90, formalin : acetic acid : 70\% ethanol). The receptacles were softened in sodium hydroxide $(8 \mathrm{M} \mathrm{NaOH})$ for $1 \mathrm{~h}$, washed with distilled water, then stained in a solution of $0.1 \%$ aniline blue (in potassium phosphate, $0.1 \mathrm{M} \mathrm{K}_{3} \mathrm{PO}_{4}$ ) overnight at $4{ }^{\circ} \mathrm{C}$. For microscopic examination, ovaries with pistils still attached were excised from the receptacles and placed on drops of glycerol on microscope slides. The samples were then flattened with a cover slip to reveal the styles and ovules.

Pollen tube growth in the style and ovule was examined under a fluorescence microscope, Olympus BX 50 (Olympus Co., Tokyo), using blue-light (455 nm) wavelength. Pollen tubes can be detected by the yellow-green fluorescence of the callose along their walls, which is not present in the style (Kho and Baer, 1968). Photographs were taken using a Canon EOS 10D digital camera (Canon Electronics, Tokyo). The growth of the pollen tube into the style and ovule were compared between growth temperatures $\left(23^{\circ} \mathrm{C} / 18^{\circ} \mathrm{C}\right.$ and $\left.30^{\circ} \mathrm{C} / 25^{\circ} \mathrm{C}\right)$ and between 'Nyoho' and 'Toyonoka'.

All statistical analyses (e.g., analysis of variance and LSD mean comparisons) were performed using the SPSS software from SPSS Inc. (Chicago).

\section{Results}

Pollen viability. The interactions among cultivar, temperature treatments, and flower positions were found to be highly significant for all flower positions in both 'Nyoho' and 'Toyonoka'.

The percentage of viable pollen was significantly lower at 30 ${ }^{\circ} \mathrm{C} / 25^{\circ} \mathrm{C}$ (high-temperature treatment) than at $23^{\circ} \mathrm{C} / 18^{\circ} \mathrm{C}$ (control) in both 'Nyoho' and 'Toyonoka' and at all flower positions, except in pollen from tertiary flowers of 'Nyoho' (Table 1). The effect of growth temperatures differed between the two cultivars. In 'Toyonoka', an increase in growth temperatures resulted in a decrease in the percentage of viable pollen by $62 \%, 42 \%$, and $27 \%$ for primary, secondary, and tertiary flowers, respectively. The corresponding values in 'Nyoho' were $12 \%, 14 \%$, and $8 \%$. When the effect of flower position was compared, the percentage of viable pollen remained almost constant in 'Nyoho' plants grown at either $23^{\circ} \mathrm{C} / 18^{\circ} \mathrm{C}$ or $30^{\circ} \mathrm{C} / 25^{\circ} \mathrm{C}$, and in 'Toyonoka' plants grown at $23{ }^{\circ} \mathrm{C} / 18{ }^{\circ} \mathrm{C}$, regardless of flower position. In 'Toyonoka' flowers developed at $30{ }^{\circ} \mathrm{C} / 25{ }^{\circ} \mathrm{C}$, however, the percentage of viable pollen increased with the increase in flower position from primary to tertiary.

IN VITRO POLLEN GERMINATION. The interactions among plant growth temperature, germination temperature, and flower position were highly significant in both 'Nyoho' and 'Toyonoka' flowers (Table 2). 
Table 1. Pollen viability percentage in 'Nyoho' and 'Toyonoka' strawberry flowers grown under two day/night temperature regimes.

\begin{tabular}{|c|c|c|c|c|}
\hline \multirow[b]{2}{*}{ Cultivar } & \multirow[b]{2}{*}{ Temp } & \multicolumn{3}{|c|}{ Flower position $^{\text {z,y }}$} \\
\hline & & Primary & Secondary & Tertiary \\
\hline \multirow[t]{2}{*}{ Nyoho } & $23^{\circ} \mathrm{C} / 18^{\circ} \mathrm{C}$ & $86.4 \mathrm{a}$ & $82.0 \mathrm{ab}$ & $77.6 \mathrm{bc}$ \\
\hline & $30^{\circ} \mathrm{C} / 25^{\circ} \mathrm{C}$ & $76.2(-11.8) c$ & $70.2(-14.4) \mathrm{d}$ & $71.4(-8.0) \mathrm{cd}$ \\
\hline \multirow[t]{2}{*}{ Toyonoka } & $23^{\circ} \mathrm{C} / 18^{\circ} \mathrm{C}$ & $79.6 \mathrm{bc}$ & $74.4 \mathrm{~cd}$ & $75.6 \mathrm{c}$ \\
\hline & $30^{\circ} \mathrm{C} / 25^{\circ} \mathrm{C}$ & $30.4(-61.8) \mathrm{g}$ & $43.0(-42.2) \mathrm{f}$ & $55.0(-27.2) \mathrm{e}$ \\
\hline \multicolumn{5}{|c|}{ Significance } \\
\hline \multicolumn{2}{|c|}{ Cultivar (C) } & \multicolumn{3}{|c|}{$* *$} \\
\hline \multicolumn{2}{|c|}{ Temperature $(\mathrm{T})$} & \multicolumn{3}{|c|}{$* *$} \\
\hline \multicolumn{2}{|c|}{ Flower position $(\mathrm{F})$} & \multicolumn{3}{|c|}{ * } \\
\hline \multicolumn{2}{|c|}{$\mathrm{CxT}$} & \multicolumn{3}{|c|}{$* *$} \\
\hline \multicolumn{2}{|c|}{$\mathrm{C} \times \mathrm{F}$} & \multicolumn{3}{|c|}{$* *$} \\
\hline \multicolumn{2}{|c|}{$\mathrm{T} \times \mathrm{F}$} & \multicolumn{3}{|c|}{$* *$} \\
\hline \multicolumn{2}{|c|}{$\mathrm{C} \times \mathrm{T} \times \mathrm{F}$} & \multicolumn{3}{|c|}{$* *$} \\
\hline \multicolumn{2}{|c|}{ Overall LSD $\operatorname{LS}_{(0.05)}$} & \multicolumn{3}{|c|}{5.3} \\
\hline
\end{tabular}

zValues with the same letter are not significantly different from each other $(P>0.05)$

y Numbers in parentheses indicate percentage decrease from control treatment.

${ }^{*, *}$ Significance at $P>0.05$ or 0.01 , respectively.

High plant growth temperatures and a high germination temperature $\left(30^{\circ} \mathrm{C} / 25{ }^{\circ} \mathrm{C}\right.$ at $30{ }^{\circ} \mathrm{C}$, HT) decreased the pollen germination percentage significantly at all flower positions of both 'Nyoho' and 'Toyonoka' compared with those from the CT treatment $\left(23^{\circ} \mathrm{C} / 18{ }^{\circ} \mathrm{C}\right.$ at $\left.23^{\circ} \mathrm{C}\right)$. However, the decrease in the germination percentages was greater in 'Toyonoka' than in 'Nyoho' pollen from primary and secondary flowers.

Ahigh germination temperature $\left(30^{\circ} \mathrm{C}\right)$ significantly decreased the germination percentage even for pollen obtained from plants grown at control temperatures (CT vs. HGT). This was evident for all flower positions in both 'Nyoho' and 'Toyonoka', but the decrease in the germination percentage was greater in 'Toyonoka' than in 'Nyoho' pollen from secondary and tertiary flowers. In plants grown at $30{ }^{\circ} \mathrm{C} / 25^{\circ} \mathrm{C}$, the pollen germination percentage was significantly higher at $23{ }^{\circ} \mathrm{C}$ (RT) than at $30{ }^{\circ} \mathrm{C}(\mathrm{HT})$ in both cultivars and at all flower positions, except for pollen from secondary flowers of 'Nyoho'.

The germination percentages of pollen developed at $30^{\circ} \mathrm{C} / 25$ ${ }^{\circ} \mathrm{C}$ and germinated at $23{ }^{\circ} \mathrm{C}$ (RT) and pollen developed at 23 ${ }^{\circ} \mathrm{C} / 18{ }^{\circ} \mathrm{C}$ and germinated at $30^{\circ} \mathrm{C}$ (HGT) were not significantly different from each other at any flower position of 'Nyoho' and in secondary flowers of 'Toyonoka', but both treatments had significantly lower germination percentages compared with the control treatment (CT) at all flower positions of both cultivars. At high germination temperatures (HGT vs. HT), the germination percentage was significantly higher in HGT than HT only for tertiary flowers of 'Nyoho' and primary flowers of 'Toyonoka'.

Pollen tube Growth. The interactions among plant growth temperature, germination temperature, and flower position were not significant in both cultivars (Table 3 ). However, the interaction between germination temperature and flower position was significant in 'Nyoho'; while in 'Toyonoka', the interactions of flower position with plant growth temperature and with germination temperature were significant.

High plant growth temperature (RT and HT) restricted pollen tube growth in 'Nyoho' as compared with pollen from plants grown at control temperatures (CT and HGT). However, germination temperature did not have a significant effect on pollen tube growth within the same growth temperature treatments.

In 'Toyonoka', pollen tube growth was restricted by high plant growth temperature (RT and HT) when compared with control temperatures (CT and HGT) in the secondary and tertiary flower positions. When the effects of germination temperatures were compared at the same plant growth temperatures, pollen tube length in 'Toyonoka' was shorter at 30 ${ }^{\circ} \mathrm{C}$ than at $23{ }^{\circ} \mathrm{C}$ in primary and secondary flowers at $23{ }^{\circ} \mathrm{C} / 18^{\circ} \mathrm{C}$ (CT vs. HGT), and in primary flowers at $30^{\circ} \mathrm{C} / 25^{\circ} \mathrm{C}$ (RT vs. HT).

The decrease in pollen tube growth was greater in 'Toyonoka' than in 'Nyoho' particularly at the HGT and HT treatments when compared with the CT treatments. But 'Nyoho' pollen showed a greater decrease in pollen tube growth than 'Toyonoka' at the primary and tertiary flower positions of the RT treatment.

The tube lengths of pollen developed at 23 ${ }^{\circ} \mathrm{C} / 18{ }^{\circ} \mathrm{C}$ and germinated at $30{ }^{\circ} \mathrm{C}$ (HGT) were longer than those of pollen developed at $30^{\circ} \mathrm{C} / 25$ ${ }^{\circ} \mathrm{C}$ and germinated at $23{ }^{\circ} \mathrm{C}$ (RT) for all flower positions of both cultivars, except for primary flowers of 'Toyonoka' and secondary flowers of 'Nyoho'.

IN VIVO POLLEN GERMINATION. Pollen germinated on the stigma (Fig. 1A) and pollen tubes were observed in the styles of flowers of both cultivars grown at either $23^{\circ} \mathrm{C} / 18^{\circ} \mathrm{C}$ or $30^{\circ} \mathrm{C} / 25^{\circ} \mathrm{C}$ (Fig. 1B). At $30^{\circ} \mathrm{C} / 25^{\circ} \mathrm{C}$, pollen tubes were observed to have entered the ovules through the micropyle in 'Nyoho' flowers (Fig. $1 \mathrm{C}$ and E). In 'Toyonoka' flowers, pollen germinated on the stigma and the pollen tube elongated through the style, but the pollen tube did not grow long enough to reach the ovule $24 \mathrm{~h}$ after pollination (Fig. 1F). Therefore, no pollen tubes could be detected in many of the ovules of 'Toyonoka' flowers (Fig. 1D).

\section{Discussion}

Pollen viability. The percentage of viable pollen decreased with an increase in growth temperatures from $23^{\circ} \mathrm{C} / 18^{\circ} \mathrm{C}$ to 30 ${ }^{\circ} \mathrm{C} / 25^{\circ} \mathrm{C}$ (Table 1 ). At $23{ }^{\circ} \mathrm{C} / 18{ }^{\circ} \mathrm{C}$, however, the percentage of viable pollen was significantly less in 'Toyonoka' than in 'Nyoho'. The effect of high temperatures on pollen viability was more evident in 'Toyonoka' than in 'Nyoho'. Poor pollen viability at high temperature has been shown to reduce fruit set in cowpea [Vigna unguiculata (L.) Walp.] (Warrag and Hall, 1984), groundnut (Arachis hypogaea L.) (Vara Prasad et al., 2001), tomato (Peet et al., 1998), and maize (Dupuis and Dumas, 1990), but not in flax (Linum usitatissimum L.) (Cross et al., 2003) and mustard [Brassica juncea (L.) Czern.] (Rao et al., 1992). Porch and Jahn (2001) reported that pollen viability is reduced at high temperatures in 
Table 2. In vitro germination percentage of pollen from 'Nyoho' and 'Toyonoka' strawberry flowers grown under two day/night temperature regimes and germinated at two temperatures.

\begin{tabular}{|c|c|c|c|c|}
\hline \multicolumn{2}{|c|}{ Temp } & \multicolumn{3}{|c|}{ Flower position, ${ }^{\mathrm{z}, \mathrm{y}}$} \\
\hline Plant growth & Germination & Primary & Secondary & Tertiary \\
\hline \multicolumn{5}{|l|}{ 'Nyoho' } \\
\hline $23^{\circ} \mathrm{C} / 18^{\circ} \mathrm{C}$ & $23^{\circ} \mathrm{C}(\mathrm{CT})^{\mathrm{x}}$ & $75.2 \mathrm{a}$ & $54.6 \mathrm{~b}$ & $56.4 \mathrm{~b}$ \\
\hline $23{ }^{\circ} \mathrm{C} / 18^{\circ} \mathrm{C}$ & $30^{\circ} \mathrm{C}(\mathrm{HGT})$ & $37.6(-50.0) \mathrm{de}$ & $37.0(-32.2) \mathrm{de}$ & $44.2(-21.6) \mathrm{c}$ \\
\hline $30^{\circ} \mathrm{C} / 25^{\circ} \mathrm{C}$ & $23{ }^{\circ} \mathrm{C}(\mathrm{RT})$ & $40.2(-46.5) \mathrm{cd}$ & $40.8(-25.3) \mathrm{cd}$ & $46.0(-18.4) \mathrm{c}$ \\
\hline $30^{\circ} \mathrm{C} / 25^{\circ} \mathrm{C}$ & $30{ }^{\circ} \mathrm{C}(\mathrm{HT})$ & $32.0(-57.4)$ ef & $35.0(-35.9) \mathrm{def}$ & $29.0(-48.6) \mathrm{f}$ \\
\hline \multicolumn{2}{|l|}{ Significance } & \multicolumn{3}{|c|}{$* *$} \\
\hline \multicolumn{2}{|c|}{ Plant growth $(\mathrm{P})$} & \multicolumn{3}{|c|}{$* *$} \\
\hline \multicolumn{2}{|c|}{ Germination $(\mathrm{G})$} & \multicolumn{3}{|c|}{$* *$} \\
\hline \multicolumn{2}{|c|}{ Flower position $(\mathrm{F})$} & \multicolumn{3}{|c|}{$* *$} \\
\hline \multicolumn{2}{|l|}{$P \times G$} & \multicolumn{3}{|c|}{$* *$} \\
\hline \multicolumn{2}{|l|}{$\mathrm{P} \times \mathrm{F}$} & \multicolumn{3}{|c|}{$* *$} \\
\hline \multicolumn{2}{|l|}{$\mathrm{G} \times \mathrm{F}$} & \multicolumn{3}{|c|}{$* *$} \\
\hline \multicolumn{2}{|l|}{$P \times G \times F$} & \multicolumn{3}{|c|}{$* *$} \\
\hline \multicolumn{2}{|l|}{$\operatorname{LSD}_{(0.05)}$} & \multicolumn{3}{|c|}{6.1} \\
\hline \multicolumn{5}{|l|}{ 'Toyonoka' } \\
\hline $23^{\circ} \mathrm{C} / 18^{\circ} \mathrm{C}$ & $23{ }^{\circ} \mathrm{C}(\mathrm{CT})$ & $55.6 \mathrm{a}$ & $56.2 \mathrm{a}$ & $40.6 \mathrm{~b}$ \\
\hline $23{ }^{\circ} \mathrm{C} / 18^{\circ} \mathrm{C}$ & $30{ }^{\circ} \mathrm{C}(\mathrm{HGT})$ & $28.2(-49.3)$ cde & $27.6(-50.9)$ cde & $29.0(-28.6) \mathrm{cd}$ \\
\hline $30^{\circ} \mathrm{C} / 25^{\circ} \mathrm{C}$ & $23{ }^{\circ} \mathrm{C}(\mathrm{RT})$ & $38.6(-30.6) b$ & $32.0(-43.1) \mathrm{c}$ & $38.0(-6.4) b$ \\
\hline $30^{\circ} \mathrm{C} / 25^{\circ} \mathrm{C}$ & $30{ }^{\circ} \mathrm{C}(\mathrm{HT})$ & $18.4(-66.9) \mathrm{f}$ & $22.8(-59.4)$ ef & $23.8(-41.4) \mathrm{def}$ \\
\hline \multicolumn{5}{|l|}{ Significance } \\
\hline \multicolumn{2}{|c|}{ Plant growth $(\mathrm{P})$} & \multicolumn{3}{|c|}{$* *$} \\
\hline \multicolumn{2}{|c|}{ Germination $(\mathrm{G})$} & \multicolumn{3}{|c|}{$* *$} \\
\hline \multicolumn{2}{|c|}{ Flower position $(\mathrm{F})$} & \multicolumn{3}{|c|}{ NS } \\
\hline \multicolumn{2}{|l|}{$P \times G$} & \multicolumn{3}{|c|}{$* *$} \\
\hline \multicolumn{2}{|l|}{$\mathrm{P} \times \mathrm{F}$} & & $* *$ & \\
\hline $\mathrm{G} \times \mathrm{F}$ & & & $* *$ & \\
\hline$P \times G \times F$ & & & $* *$ & \\
\hline $\operatorname{LSD}_{(0.05)}$ & & & 5.7 & \\
\hline
\end{tabular}

${ }^{2}$ Values with the same letter are not significantly different from each other $(P>0.05)$. yNumbers in parentheses indicate percentage decrease (-) or increase (+) from CT. ${ }^{\mathrm{x}} \mathrm{CT}=$ control temperature; $\mathrm{RT}=$ relieving temperature; $\mathrm{HGT}=$ high germination temperature; and $\mathrm{HT}=$ high temperature.

NS, ${ }^{* * *}$ Nonsignificance or significance at $P>0.05$ or 0.01 , respectively.

heat-sensitive genotypes of bean, which in turn causes a reduction in yield. Braak (1968) found that the absence of viable pollen was the cause of poor fruit set in 'Jucunda' strawberries. According to Kronenberg (1959), pollen viability differs among strawberry cultivars, with those having a high percentage of viable pollen likely to have a high percentage of fruit set. These differences in pollen viability among cultivars were observed in 'Nyoho' and 'Toyonoka' and could possibly result in a lower fruit set in the latter cultivar. Our preliminary studies show that in plants grown at $30^{\circ} \mathrm{C} / 25^{\circ} \mathrm{C}$, fruit set percentage in 'Toyonoka' was lower than in Nyoho. We also found that when compared with plants grown at $23{ }^{\circ} \mathrm{C} / 18^{\circ} \mathrm{C}$, the decrease in fruit set percentage was greater in 'Toyonoka' than in 'Nyoho' (unpublished results).

The precise mechanism that reduces pollen viability has not been reported for strawberry. In cowpea, however, reductions in pollen viability reflect the premature degeneration of the tapetal layer (Ahmed et al., 1992) and the inhibition of proline accumulation in pollen grains (Mutters et al., 1989), which is necessary for pollen development during microsporogenesis.

The effect of high temperature on pollen viability in tomato varies with the stage of pollen development (Sugiyama et al., 1966). In strawberry, Kronenberg (1959) found that primary flowers contain more nonviable pollen with the viability increasing in late-developed flowers. In our study, pollen viability increased from primary to secondary and tertiary flowers only in 'Toyonoka' grown at $30{ }^{\circ} \mathrm{C} / 25^{\circ} \mathrm{C}$. For pollen of both cultivars developed at $23^{\circ} \mathrm{C} / 18^{\circ} \mathrm{C}$, viability was always highest in the primary flowers.

Although pollen viability was lower at $30^{\circ} \mathrm{C} / 25^{\circ} \mathrm{C}$ than at $23^{\circ} \mathrm{C} / 18^{\circ} \mathrm{C}$ in both cultivars, the low percentage of viable pollen at $30^{\circ} \mathrm{C} / 25^{\circ} \mathrm{C}$ might still be enough for good fertilization. Therefore, it is possible that other factors are involved in successful fertilization, such as pollen germination and eventual tube growth. Herold (1941) found a strong correlation between the percentages of viable pollen and germinating pollen in strawberry.

IN VITRO POLLEN GERMINATION. High plant growth temperatures during pollen development significantly decreased the in vitro germination percentage at all flower positions of both 'Nyoho' and 'Toyonoka' (Table 2). However, a germination temperature of $23{ }^{\circ} \mathrm{C}$ alleviated the negative effects of high growth temperatures on the pollen of both cultivars (RT vs. $\mathrm{HT}$ ). A high germination temperature (HGT and HT) also significantly decreased the pollen germination percentage at all flower positions of both cultivars when compared with the control treatment (CT). The decrease in germination percentage was more evident in 'Toyonoka' than in 'Nyoho'. This suggests that for 'Toyonoka' the temperature during germination is more crucial to pollen germination than the temperature during its development before anthesis. Further evidence for this can be gleaned by comparing the germination percentages among CT, HGT, and RT.

Pollen tube Growth. Pollen quality is measured not only by its ability to germinate but also by the ability of the pollen tube to elongate down the style for successful fertilization. The negative effect of high plant growth temperatures on pollen tube growth was evident at all flower positions in both cultivars (Table 3), especially in 'Toyonoka'. But the effect of germination temperature was less distinct. This implies that plant growth temperature during pollen development influences pollen tube growth more strongly than the germination temperature in 'Toyonoka', whereas there was no significant response in 'Nyoho' to different germination temperatures. This could be an indication that the elongation of 'Toyonoka' pollen tubes is more sensitive to heat than that of 'Nyoho'.

The adverse effects of high temperature on pollen germination and pollen tube growth have been reported for groundnut (Kakani et al., 2002; Talwar and Yanagihara, 1999), rice (Oryza sativa L.) (Yoshida et al., 1981), and pecan (Yates and Sparks, 1993). In tobacco pollen, an increase in germination temperature from 25 to $35^{\circ} \mathrm{C}$ decreases tube growth by $50 \%$ (Kandasamy and Kristen, 1989). Our study also found adverse effects of high temperatures on strawberry pollen of 'Nyoho' and 'Toyonoka'. However, the effect was more evident in 'Toyonoka' than in 'Nyoho', suggesting that 'Toyonoka' pollen is heat sensitive, while 'Nyoho' pollen 
Table 3. Tube length of in vitro germinated pollen from 'Nyoho' and 'Toyonoka' strawberry flowers grown under two day/night temperature regimes and germinated at two temperatures.

\begin{tabular}{|c|c|c|c|c|}
\hline \multicolumn{2}{|c|}{ Temp } & \multicolumn{3}{|c|}{ Flower position ${ }^{\mathrm{z}, \mathrm{y}}$} \\
\hline Plant growth & Germination & Primary (mm) & Secondary (mm) & Tertiary $(\mathrm{mm})$ \\
\hline \multicolumn{5}{|l|}{ 'Nyoho' } \\
\hline $23{ }^{\circ} \mathrm{C} / 18^{\circ} \mathrm{C}$ & $23^{\circ} \mathrm{C}(\mathrm{CT})^{\mathrm{y}}$ & $3.72 \mathrm{a}$ & $3.40 \mathrm{ab}$ & $3.24 \mathrm{ab}$ \\
\hline $23^{\circ} \mathrm{C} / 18^{\circ} \mathrm{C}$ & $30^{\circ} \mathrm{C}(\mathrm{HGT})$ & $3.61(-3.0) \quad a b$ & $3.12(-8.2) \quad b c$ & $3.42(+5.6) \mathrm{ab}$ \\
\hline $30^{\circ} \mathrm{C} / 25^{\circ} \mathrm{C}$ & $23{ }^{\circ} \mathrm{C}(\mathrm{RT})$ & $2.64(-29.0) \mathrm{cd}$ & $2.66(-21.8) \mathrm{cd}$ & $2.42(-25.3) \mathrm{d}$ \\
\hline $30^{\circ} \mathrm{C} / 25^{\circ} \mathrm{C}$ & $30{ }^{\circ} \mathrm{C}(\mathrm{HT})$ & $2.64(-29.0) \mathrm{cd}$ & $2.36(-30.6) \mathrm{d}$ & $2.68(-17.3) \mathrm{cd}$ \\
\hline \multicolumn{5}{|l|}{ Significance } \\
\hline \multicolumn{2}{|c|}{ Plant growth $(\mathrm{P})$} & \multicolumn{3}{|c|}{$* *$} \\
\hline \multicolumn{2}{|c|}{ Germination (G) } & \multicolumn{3}{|c|}{ NS } \\
\hline \multicolumn{2}{|c|}{ Flower position $(\mathrm{F})$} & \multicolumn{3}{|c|}{ * } \\
\hline \multicolumn{2}{|l|}{$P \times G$} & \multicolumn{3}{|c|}{ NS } \\
\hline \multicolumn{2}{|l|}{$\mathrm{P} \times \mathrm{F}$} & \multicolumn{3}{|c|}{ NS } \\
\hline \multicolumn{2}{|l|}{$\mathrm{G} \times \mathrm{F}$} & \multicolumn{3}{|c|}{$*$} \\
\hline \multicolumn{2}{|l|}{$P \times G \times F$} & \multicolumn{3}{|c|}{ NS } \\
\hline \multicolumn{2}{|l|}{$\operatorname{LSD}_{(0.05)}$} & \multicolumn{3}{|c|}{0.54} \\
\hline \multicolumn{5}{|l|}{ 'Toyonoka' } \\
\hline $23^{\circ} \mathrm{C} / 18^{\circ} \mathrm{C}$ & $23{ }^{\circ} \mathrm{C}(\mathrm{CT})$ & $3.04 \mathrm{ab}$ & $3.52 \mathrm{a}$ & $2.90 \mathrm{~b}$ \\
\hline $23^{\circ} \mathrm{C} / 18^{\circ} \mathrm{C}$ & $30^{\circ} \mathrm{C}$ (HGT) & $2.24(-26.3)$ cde & $2.72(-22.7) b c$ & $2.96(+2.1) b$ \\
\hline $30^{\circ} \mathrm{C} / 25^{\circ} \mathrm{C}$ & $23{ }^{\circ} \mathrm{C}(\mathrm{RT})$ & $2.25(-25.9)$ cde & $1.92(-45.5) \mathrm{def}$ & $2.30(-20.7) \mathrm{cd}$ \\
\hline $30^{\circ} \mathrm{C} / 25^{\circ} \mathrm{C}$ & $30{ }^{\circ} \mathrm{C}(\mathrm{HT})$ & $1.67(-45.1) \mathrm{f}$ & $1.70(-51.7)$ ef & $2.16(-25.5) \mathrm{def}$ \\
\hline \multicolumn{5}{|l|}{ Significance } \\
\hline \multicolumn{2}{|c|}{ Plant growth $(\mathrm{P})$} & \multicolumn{3}{|c|}{$* *$} \\
\hline \multicolumn{2}{|c|}{ Germination (G) } & \multicolumn{3}{|c|}{$* *$} \\
\hline \multicolumn{2}{|c|}{ Flower position $(\mathrm{F})$} & \multicolumn{3}{|c|}{$*$} \\
\hline \multicolumn{2}{|l|}{$P \times G$} & \multicolumn{3}{|c|}{ NS } \\
\hline \multicolumn{2}{|l|}{$P \times F$} & \multicolumn{3}{|c|}{$* *$} \\
\hline GxF & & & $* *$ & \\
\hline$P \times G \times F$ & & & NS & \\
\hline $\operatorname{LSD}_{(0.05)}$ & & & 0.56 & \\
\hline
\end{tabular}

zValues with the same letter are not significantly different from each other $(P>0.05)$. yNumbers in parentheses indicate percentage decrease $(-)$ or increase $(+)$ from CT.

${ }^{\mathrm{x}} \mathrm{CT}=$ control temperature; $\mathrm{RT}=$ relieving temperature $; \mathrm{HGT}=$ high germination temperature; and $\mathrm{HT}=$ high temperature.

NS, ${ }^{*}, * *$ Nonsignificance or significance at $P>0.05$ or 0.01 , respectively

possesses a certain degree of heat tolerance. Furthermore, we found that plant growth temperature and germination temperature had different effects on pollen germination and pollen tube growth in 'Nyoho': while both factors had significant effects on the percentage of germination, only plant growth temperature had a significant influence on pollen tube growth. This finding differs from the report of Kakani et al. (2002) for groundnut in which they stated that pollen tube growth is more dependent on the germination temperature than the temperature under which pollen develops. In Cucurbita pepo, Johansson and Stephenson (1998) found that pollen developed under cool conditions (20 ${ }^{\circ} \mathrm{C}$ ) had significantly longer pollen tubes than pollen developed under warm conditions $\left(30^{\circ} \mathrm{C}\right)$, regardless of whether the pollen was germinated under cool or warm conditions. However, their results also showed that cool- and warm-developed pollen had significantly longer pollen tubes when germinated under warm conditions than when germinated under cool conditions. The dif- ferent results between strawberry and Cucurbita pepo may be due to differences in the climatic requirements of the two crops, that is, the strawberry is a winter-spring crop and requires low temperatures for optimum growth, whereas zucchini is a spring-summer crop requiring warmer temperatures.

Microsporogenesis is considered to be the stage most sensitive to high temperatures in other crop species. This stage occurs 7 to $9 \mathrm{~d}$ before anthesis (DBA) in tomato (Iwahori, 1966) and 3 to 5 DBA in peanut (Arachis hypogaea L.) (Talwar and Yanagihara, 1999). Sakata et al. (2000) reported that in barley (Hordeum vulgare L.) pollen there are at least three reproductive growth stages most sensitive to high temperature. Our strawberry plants were exposed to the temperature treatments when the first inflorescence became visible, this corresponded to approximately 12 DBA under control conditions. Determining the most sensitive stage to high temperature in the development of strawberry pollen requires further study.

IN VIVO POLLEN GERMINATION. After pollination, fertilization in strawberry plants is completed within $24 \mathrm{~h}$ (Hancock, 1999). Hence, we examined in vivo pollen germination at $23{ }^{\circ} \mathrm{C} / 18{ }^{\circ} \mathrm{C}$ and $30^{\circ} \mathrm{C} / 25^{\circ} \mathrm{C}$ in 'Nyoho' and 'Toyonoka' primary, secondary and tertiary flowers $24 \mathrm{~h}$ after pollination (Fig. 1). At 30 ${ }^{\circ} \mathrm{C} / 25^{\circ} \mathrm{C}$, pollen tubes were observed in the ovules of 'Nyoho' flowers (Fig. $1 \mathrm{C}$ and E), while pollen tubes failed to enter the ovules in many of the 'Toyonoka' flowers (Fig. $1 \mathrm{D}$ and F). These observations provide strong evidence for the differences in the effect of hightemperature stress on pollen tube elongation between 'Nyoho' and 'Toyonoka'. Restrictions in pollen tube elongation have also been found under heat stress conditions in tobacco (Shivanna et al., 1991) and flax (Cross et al., 2003).

In conclusion, high temperatures reduce pollen viability, germinability and pollen tube growth, particularly in 'Toyonoka', which could result in low fruit set in this cultivar. Successful pollination is very important in strawberry plants because only fertile ovaries can promote the enlargement of the receptacle (i.e., the development of the fruit). When all ovaries in a receptacle are fertilized, a well-shaped, marketable fruit develops. We have also shown that pollen from different strawberry cultivars have differing responses to high-temperature stress. This information could be useful for improving heat tolerance in strawberry.

\section{Literature Cited}

Abdul-baki, A.A. and J.R. Stommel. 1995. Pollen viability and fruit-set of tomato genotypes under optimum-temperature and high-temperature regimes. HortScience 30:115-117.

Ahmed, F.E., A.E. Hall, and D.A. Demason. 1992. Heat injury during floral development in cowpea (Vigna unguiculata Fabaceae). Amer. J. Bot. 79:784-791.

Aloni, B., M. Peet, M. Pharr, and L. Karni. 2001. The effect of high temperature and high atmospheric $\mathrm{CO}_{2}$ on carbohydrate changes in bell pepper (Capsicum annum) pollen in relation to its germination. Physiol. Plant. 112:505-512.

Austin, P.T., E.W. Hewett, D. Noitin, and J.A. Plummer. 1998. Self incompatibility and temperature affect pollen tube growth in 'Sundrop' 

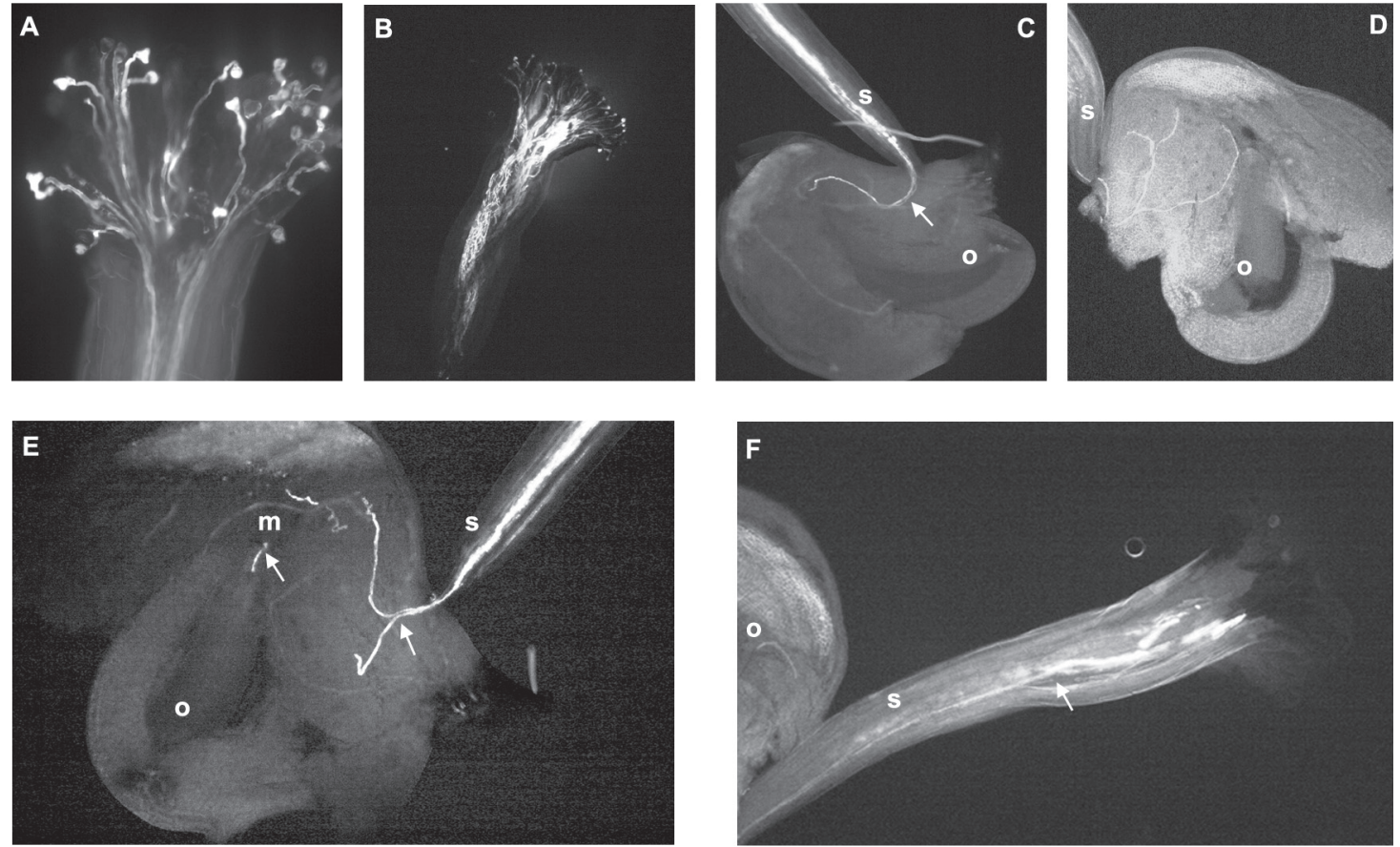

Fig. 1. Pollen germination in vivo examined by fluorescence microscopy. (A) Pollen germinating on the stigma; (B) pollen tubes extending through the style; (C) a pollen tube in 'Nyoho' (white arrow) entering the ovule; (D) a style and ovule without pollen tubes commonly observed in 'Toyonoka' flowers from the $30^{\circ} \mathrm{C} / 25^{\circ} \mathrm{C}$ treatment; (E) a pollen tube entering the micropyle in 'Nyoho' flowers from the $30^{\circ} \mathrm{C} / 25^{\circ} \mathrm{C}$ treatment; and $(\mathbf{F})$ a pollen tube in 'Toyonoka' flowers from the $30{ }^{\circ} \mathrm{C} / 25^{\circ} \mathrm{C}$ treatment failed to enter the ovule $24 \mathrm{~h}$ after pollination. Magnified $200 x ; \mathrm{s}=$ style; $\mathrm{m}=$ micropyle; $\mathrm{o}=$ ovule.

apricot (Prunus armeniaca L.). J. Amer. Soc. Hort. Sci. 73:375-386. Braak, J.P. 1968. Some causes of poor fruit set in Jucunda strawberries. Euphytica 17: 311-318.

Cross, R.H., S.A.B. Mckay, A.G. Mchughen, and P.C. Bonham-Smith. 2003. Heat-stress effects on reproduction and seed set in Linum usitatissimum L. (Flax). Plant Cell Environ. 26:1013-1020.

Dane,F.,A.G. Hunter, and O.L. Chambliss. 1991. Fruit set, pollen fertility, and combining ability of selected tomato genotypes under high-temperature field conditions. J. Amer. Soc. Hort. Sci. 116:906-910.

Dupuis, I. and C. Dumas. 1990. Influence of temperature stress on in vitro fertilization and heat shock protein synthesis in maize (Zea mays L.) reproductive tissue. Plant Physiol. 94:665-670.

Gilbert, C. and P.J. Breen. 1986. Low pollen production as a cause of fruit malformation in strawberry. J. Amer. Soc. Hort. Sci. 111:56-60.

Hancock, J.E. 1999. Strawberries. CABI, New York.

Herold, G. 1941. Sortenprüfung bei Erdbeeren unter besonderer Berücksichtigung der Befruchtungsverhältnisse. Gartenbauwiss $16: 216-262$.

Iwahori, S. 1966. High temperature injuries in tomato. V. Fertilization and development of embryo with special reference to the abnormalities caused by high temperature. J. Jpn. Soc. Hort. Sci. 35:55-62.

Johansson, M.H. and A.G. Stephenson. 1998. Effects of temperature during microsporogenesis on pollen performance in Cucurbita pepo L. (Cucurbitaceae). Intl. J. Plant Sci. 159:616-626.

Kakani, V.G., P.V.V. Prasad, P.Q. Craufurd, and T.R. Wheeler. 2002. Response on in vitro pollen germination and pollen tube growth of groundnut (Arachis hypogea L.) genotypes to temperature. Plant Cell Environ. 25:1651-1661.

Kandasamy, M.K. and U. Kristen. 1989. Ultrastructural responses of tobacco pollen tubes to heat shock. Protoplasma 153:104-110.

Kho, Y.O. and J. Baer. 1968. Observing pollen tubes by means of fluorescence. Euphytica 17:298-302.

Kim, S.Y., C.B. Hong, and I. Lee. 2001. Heat shock stress causes stage-specific male sterility in Arabidopsis thaliana. J. Plant Res. 114:301-307.
Kronenberg, H.G. 1959. Poor fruit setting in strawberries. I. Causes of poor fruit setting in strawberries in general. Euphytica 8:47-57.

Lyakh, V.A., A.N. Kravchenko, A.I. Soroka, and E.N. Dryuchina. 1991. Effects of high temperature on mature pollen grains in wild and cultivated maize accessions. Euphytica 55:203-207.

Mutters, R.G., L.G.R. Ferreira, and A.E. Hall. 1989. Proline content of the anthers and pollen of heat-tolerant and heat-sensitive cowpea subjected to different temperatures. Crop Sci. 29:1497-1500.

Peet, M., S. Sato, and R.G. Gardner. 1998. Comparing heat stress effects on male-fertile and male-sterile tomatoes. Plant Cell Environ. 21:225-231.

Porch, T.G. and M. Jahn. 2001. Effects of high temperature stress on microsporogenesis in heat-sensitive and heat-tolerant genotypes of Phaseolus vulgaris. Plant Cell Environ. 24:723-731.

Rao, G.U., A. Jain, and K.R. Shivanna. 1992. Effects of high temperature stress on Brassica pollen: Viability, germination and ability to set fruits and seeds. Ann. Bot. 68:193-198.

Risser, G. 1997. Effect of low temperatures on pollen production and germination in strawberry. Acta Hort. 439:651-658.

Sakata. T., H. Takahashi, I. Nishiyama, and A. Higashitani. 2000. Effects of high temperature on the development of pollen mother cells and microspores in barley Hordeum vulgare L. J. Plant Res. 113:395-402.

Sato, S., M.M. Peet, and J.F. Thomas. 2000. Physiological factors limit fruit set of tomato (Lycopersicon esculentum Mill.) under chronic, mild heat stress. Plant Cell Environ. 23:719-726.

Shivanna, K.R.,H.F.Linskens, and M. Cresti. 1991. Responses of tobacco pollen to high humidity and heat-stress - Viability and germinability invitro and invivo. Sex. Plant Reprod. 4:104-109.

Smeets, L. 1976. Effect of light intensity during flowering on stamen development in the strawberry cultivar 'Glasa'. Scientia Hort. 4:255-260.

Smeets, L. 1980. Effect of light intensity during flowering on stamen development in the strawberry cultivar 'Karina' and 'Sivetta'. Scientia Hort. 12:343-346.

Song, J., K. Nada, and S. Tachibana. 1999. Ameliorative effect of 
polyamines on the high temperature inhibition of in vitro pollen germination in tomato (Lycopersicon esculentum Mill.). Scientia Hort. 80:203-212.

Strick, B.C. 1985. Flower bud initiation in strawberry cultivars. Fruit Var. J. 39:5-9

Sugiyama, T., S. Iwahori, and T. Takahashi. 1966. Effect of high temperature on fruit setting of tomato under cover. Acta Hort. 5:37-54.

Talwar, H.S. and S. Yanagihara. 1999. Physiological basis of heat tolerance during flowering and pod setting stages in groundnut (Arachis hypogaea L.), p. 47-65. In: M. Yajima and T. Hayashi (eds.). JIRCAS Working Report No. 14: Proc. of Workshop on Heat-Tolerance of Crops. Japan Intl. Res. Center for Agric. Sci., Tsukuba City, Japan.

Vara Prasad, P.V., P.Q. Craufurd, V.G. Kakani, T.R. Wheeler, and K.J. Boote. 2001. Influence of high temperature during pre- and post-an- thesis stages of floral development on fruit-set and pollen germination in peanut. Aust. J. Plant Physiol. 28:233-240.

Voyiatzis, D.G. and G. Paraskevopoulou-Paroussi. 2002. Factors affecting the quality and in vitro germination capacity of strawberry pollen. J. Hort. Sci. Biotech. 77:200-203.

Warrag, M.O.A. and A.E. Hall. 1984. Reproductive responses of cowpea (Vigna unguiculata (L.) Walp.) to heat stress. II. Responses to night air temperature. Field Crops Res. 8:17-33.

Yates, I.E. and D. Sparks. 1993. Environmental regulation of anther dehiscence and pollen germination in pecan. J. Amer. Soc. Hort. Sci. 118:699-706.

Yoshida, S., J. Satake, and D.J. Mackill. 1981. High temperature stress in rice. IRRI Res. Paper Ser. 67. Intl. Rice Res. Inst., Los Baños, Philippines. 